\title{
Merger announcements and share price return — the role of the relationship between acquiring and target firms
}

\author{
R.C. van den Honert and G.D.I. Barr* \\ Department of Mathematical Statistics, University of Cape Town, Private Bag, Rondebosch, 7700 Republic of South Africa \\ J.F. Affleck-Graves and G.Smale \\ Graduate School of Business, University of Cape Town, Private Bag, Rondebosch, 7700 Republic of South Africa
}

Received II August 1987; accepted 28 September 1987

\begin{abstract}
The authors examine, in a cumulative average abnormal return (CAAR) framework, the effect of four easily identifiable features of merger activity on acquirer/target shareholder wealth. The features considered are the relatedness of the acquiring and target firms involved in the merger, the relative sizes of the acquirer and target, the prior control position, and the medium of exchange. The results indicate that the relatedness of the acquirer and target firm and the prior control position are strong factors in determining the distribution of any wealth effects between the shareholders of the target and acquiring firms. The size and the medium of exchange are shown to be weaker factors in determining the distribution of wealth. In all cases it is seen that the shareholders of acquiring firms do not tend to benefit in the short term from the merger while those of the target firms show significant gains.
\end{abstract}

Die effek van vier maklik identifiseerbare eienskappe van samesmelting van maatskappye op aandeelhouerrykdom word ondersoek in 'n raamwerk van kumulatiewe gemiddelde abnormale opbrengs. Die eienskappe wat in ag geneem word, is die verwantskap tussen die oornemende en die oorgenome maatskappye wat in die samesmelting betrokke is, die relatiewe grootte van die betrokke maatskappye, die voorafgaande beheersposisie en die medium van verwisseling. Die resultate toon dat die verwantskap tussen betrokke maatskappye en die voorafgaande beheersposisie albei sterk faktore is in die bepaling van die verspreiding van enige rykdomeffekte tussen die aandeelhouers van die betrokke maatskappye. Die relatiewe grootte en die medium van verwisseling is swakker faktore in die bepaling van die verspreiding van rykdom. In elke geval is daarop gewys dat die aandeclhouers van die oornemende maatskappye geen korttermyn voordeel uit die samesmelting kry nie, terwyl die aandeelhouers van die oorgenome maatskappye betekenisvolle winste toon.

* To whom correspondence should be addressed

\section{Introduction}

The high level of merger activity on international markets in recent years has given rise to substantial work on the subject in the current financial literature. The discussion and analysis focused strongly on the distribution of any wealth changes between the parties participating in the merger. One main thrust of this work has considered the asymmetry of returns that accrue to shareholders of acquiring and acquired firms. AffleckGraves, Flach \& Jacobson (1987) have considered this issue for the Johannesburg Stock Exchange and have established that shareholders of the acquired firms experience abnormal positive returns immediately prior to the announcement date, but could find no evidence that shareholders of the acquiring companies benefit by merger activity in the short term. Their conclusions were consistent with research on the New York Stock Exchange (see Mandelker, 1974; Langetieg, 1978; Dodd, 1980; Shad, 1969; Jensen \& Ruback, 1983).

An obvious question which flows from the above is whether the level of any excess return experienced by target and acquiring firms can be related to the characteristics of the merger. In this paper we consider this issue for a set of mergers on the JSE over the period 1975 to 1985 . The study will focus on four easily identifiable features of merger activity which describe the relationship between the target and acquiring firms and the mechanics of the merger and aim to quantify the wealth effect of these four features for shareholders of the target and acquiring firms. The features considered are the relatedness of the acquiring and target firms involved in the merger, the relative sizes of the acquirer and target, the prior control position and the medium of exchange. In a recent study Brews (1987) has considered the effect of relatedness and size on merger activity but has not quantified these effects.

We first discuss why these four factors may be important for merger activity and how they are defined for the purposes of this study. In a cumulative average abnormal return framework we then determine their effect on acquirer and target shareholder wealth.

\section{Characteristics which describe merger activity}

Related and unrelated mergers

Brews (1987) cites the nature of the business of the target firm relative to that of the acquiring firm as perhaps the most important characteristic in the profile of a prospective target firm. It may seem that by acquiring an unrelated asset, a firm is diversifying which should lead to a reduction in risk. Brews and others (see, for example, Peters \& Waterman, 1982) have, however, found that firms that branch out into unrelated fields are likely to be less successful in the long run since they do not know the business of the prospective target firm. Thus it is of interest to determine the extent to which wealth gains accrue to shareholders of acquiring and 
target firms which engage in mergers with firms in related industries on the one hand, and to shareholders of acquiring and target firms which engage in mergers with firms in unrelated industries on the other.

A merger was classified 'related' if the target firm was in a related industry to the acquiring firm and the acquiring firm was operating in a specific industry, i.e. was not of a conglomerate nature.

\section{Prior control of the target firm by the acquiring firm}

As an extension of the question of relatedness of acquiring and target firms it is usually assumed that if an acquiring firm already holds a controlling interest in a potential target firm it is deeply involved in that line of business and thus able to perceive the benefits to be had from the purchase of the minority interest. Furthermore, the problems involved in the postmerger integration of the target firm within the acquiring firm would already have been considered.

Mergers were thus divided into two groups: those where the acquiring firm had effective control of the target, and those where the acquirer did not have control.

\section{Relative size of the target firm to the acquiring firm}

Brews (1987) investigated the size of the target firm as a merger criterion. Whether size of the target firm was measured relative to the size of the acquiring firm ('size" of the firm could be before tax profit, turnover, market capitalization or any other measure) or in absolute terms, the conclusions were clear: firms should be wary of acquiring firms very much smaller than themselves. 'The management time and effort required to negotiate and implement such a transaction, and indeed correct matters should this go awry, is usually exorbitant' (Brews, 1987). Size mismatch has also been isolated as a major cause of failure by Kitching (1967) and Rowlinson (1984). It is thus of interest to determine whether wealth gains to the shareholders of acquiring and target firms is related to the size of the target.

A merger was classified as 'large' if the market capitalization of the target firm was more than $25 \%$ of the market capitalization of the acquiring firm at the announcement date.

\section{The medium of exchange}

Firms with a surplus of cash and a shortage of good investment opportunities often turn to mergers as a way of redeploying capital (see, for example, Brealey \& Myers, 1981). In fact, failure to do so may induce a predator firm to attempt a takeover and redeploy the capital for them. Brews (1987) found that certain South African companies used surplus cash for merger activity since they felt they were in a strong negotiating position. Thus the fourth attribute investigated was the difference in wealth accruing to shareholders of both acquiring and target firms where the merger was financed by cash only (cash-rich acquirers) or by shares only.

\section{Data collection}

This study examines a set of 45 mergers on the Johannesburg Stock Exchange (JSE) over the period $1975-1985$. These were selected out of a potential set of 105 identified by the JSE Monthly Bulletin by applying the following criteria:

(a) Complete merger information had to be available in the documentation held in the JSE archives.

(b) The acquiring firm must not have engaged in two mergers or acquisitions less than one year apart.

(c) The announcement date had to be after March 1976 to ensure at least two years of weekly share price data for the estimation of the parameter model.

(d) The average annual trading volume of the acquiring firm's shares (calculated over the four years prior to the merger and the year subsequent to the merger) had to have been greater than 100 000. Many shares quoted on the JSE are thinly traded, thus reducing the efficiency of the market in those shares, a basic assumption for this research.

This sample of $\mathbf{4 5}$ mergers was then bisected in four different ways according to the attributes outlined above. In particular the divisions were made as follows ${ }^{1}$ : sample 1.1 - unrelated mergers ( 25 mergers) sample 1.2 - related mergers (17 mergers) sample 2.1 - prior control greater than $50 \%(17$ mergers)

sample 2.2 - prior control less than $50 \%$ (24 mergers) sample 3.1 - large acquisitions (25 mergers) sample 3.2 - small acquisitions ( 17 mergers) sample 4.1 - share exchange acquisitions (18 mergers) sample 4.2 - cash exchange acquisitions (17 mergers).

A complete list of the 45 mergers, as well as the subsamples can be found in Appendix A.

On the basis of the above, the following information was collected for each acquiring and target firm:

(i) Weekly share prices of both acquiring and target firms from four years prior to the merger announcement to one year after the announcement (for target firms the data terminated when the firm was delisted at the effective date of the merger).

(ii) Weekly values of the JSE Industrial and JSE Sector indexes for the same five year period.

(iii) The number of shares in issue at the announcement date.

(iv) The date of the first public announcement of the merger.

(v) The prior holdings of the acquiring firm in the target firm at the date of the announcement.

(vi) The terms and method of financing the merger.

\section{Research methodology}

Throughout this study all computations were based on returns rather than the original price data. The weekly returns for each acquiring and target firm's merger through to one year after the merger (10 weeks after the merger in the case of target firms) were computed as: 
$R_{i t}=\frac{P_{i t}-P_{i t-1}}{P_{i t-1}} \times 100$

where $P_{i t}=$ price of share $i$ in period $t ; P_{i t-1}=$ price of share $i$ in period $t-1$.

The returns on the market and the relevant industry (or sector) indexes were computed using the same method.

In order to focus on merger-specific information the market-wide and sector-wide information must first be removed from the security returns. The mathematical model used here to remove market and sector effects is the 2-factor market-industry model used by Halpern (1973) and represents a straightforward extension of the market model used by Fama, Fisher, Jensen \& Roll (1969). Although both these models were used in the Affleck-Graves, Flach \& Jacobson (1987) study and gave similar results it was decided to use the 2-factor market industry model as it encompasses the simpler market model, and allows for adjustments for both market-wide and industry-spccific movements. It can be written in stochastic form as

$R_{i t}=\beta_{0}+\beta_{1} R_{m i}+\beta_{2} S_{i t}+\epsilon_{i t}$

where $R_{i t}=$ return on share $i$ in period $t ; R_{m}=$ return on the market in period $t ; S_{i t}=$ return on the sector in which share $i$ is listed in period $t ; \boldsymbol{\epsilon}_{i t}$ stochastic error term $\beta_{0}, \beta_{1}$ and $\beta_{2}$ are the regression coefficients ${ }^{2}$.

The parameters of the model in equation (1) were estimated using ordinary least squares regression. For each share the weekly returns for that share were regressed against the weekly returns on the market index and the particular sector index in which the share is listed for the three years prior to the year preceding the merger. An estimate of expected returns for each share for each week for the two year period surrounding the merger announcement was then calculated by taking the expectation of model (1) above and substituting the estimates of the regression coefficients for the true values of these parameters. This yields

$$
E\left(R_{i t}\right)=\hat{\beta}_{0}+\hat{\beta}_{1} R_{m t}+\hat{\beta}_{2} S_{i t}
$$

where $\hat{\beta}_{0}, \hat{\beta}_{1}$ and $\hat{\beta}_{2}$ are the ordinary least squares estimates of $\beta_{0}, \beta_{1}$ and $\beta_{2}$. The difference between the actual return observed for any share $i$ in period $t$ and the expected value of the return as calculated in equation (2) above represents that part of the return unrelated to the market or the sector. This is commonly known as the abnormal return for share $i$ in week $t\left(A R_{i t}\right)$. Thus

$$
A R_{i t}=R_{i t}-E\left(R_{i t}\right) .
$$

The abnormal returns $\left(A R_{i t}, i=1 \ldots .45, t=1 \ldots .105\right)$ were calculated for each of the 45 acquiring and 45 target firms for the 105 weeks in the prediction period. In the case of target firms which are delisted subsequent to the merger, the period of estimation stopped 10 weeks after the merger announcement week as this was the earliest delisting date in the merger sample.

It may be noted that a downward bias may be exerted on the $A R$ 's for mergers of firms operating in a market sector which is dominated by the market capitalization of that firm. In this case the sector index would tend to reflect merger-related information rather than the fundamentals of that particular industry, and thus the abnormal returns would be reduced for that merger. In such a case the actual merger gains would tend to be slightly higher than those presented here.

The weekly abnormal returns for each share were then aligned according to their announcement dates and averaged over the entire sample for each week during the 105 week prediction period and cumulated from 52 weeks prior to the announcement through to 52 weeks after the announcement for acquiring firms and 10 weeks after the announcement in the case of target firms. The cumulated average abnormal return (CAAR) for a sample of $N$ firms in week $p$ relative to the merger announcement ( $p$-th week in 'announcement time') may then be calculated as follows:

$\mathrm{CAAR}_{\mathrm{p}}=\sum_{t=-52}^{p}\left(\sum_{i=1}^{N} A R_{i t} / N\right)$

In an efficient capital market the $A R$ and $C A A R$ plots should follow a random walk with an expected value of 0 . The trend in the CAAR should reflect the reaction of the market to newly available information that has a bearing on the value of the firm.

\section{Results}

\section{Related vs unrelated mergers}

The CAAR plot for acquiring firms in the 25 unrelated mergers is shown in Figure 1.

The CAAR exhibits a downward trend in the year prior to the merger. This indicates worsening investor confidence and expectations on the future cash flows of

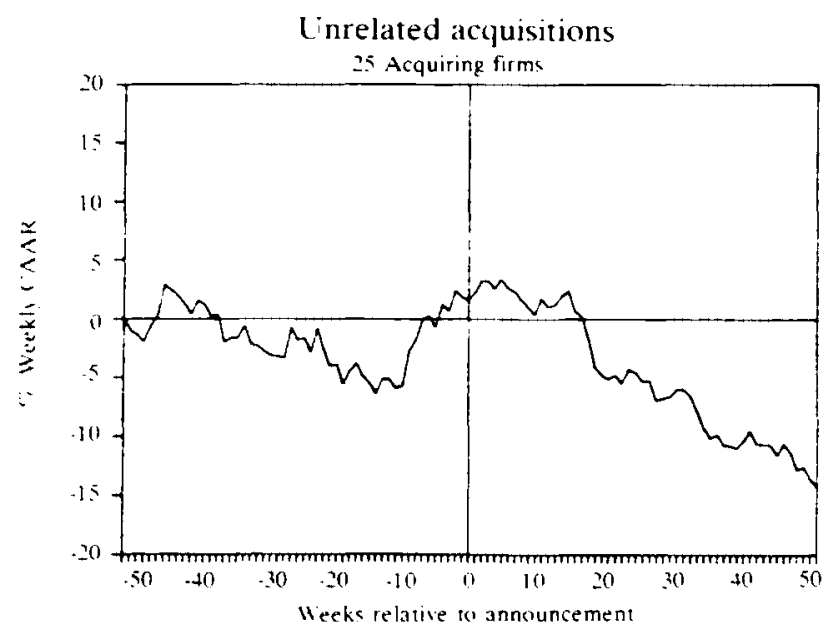

Figure 1 CAAR plot for acquiring firms in unrelated mergers (sample 1.1) 
the firm. Some 12 weeks prior to the merger announcement, however, the CAAR shows a strong upward trend which reaches a peak of $3 \%$ within four weeks of the merger announcement. Investors' expectations are subsequently revised and the net CAAR a year after the announcement is some $-14 \%$. A justification for the acquisition of an unrelated asset which is often cited is that of diversification and hence risk reduction. If this is the motive of acquiring firms included in this sample then there is no evidence that the market values this increased diversification. After all, it is easier for the shareholder himself to diversify by buying shares in an unrelated firm rather than for the firm to diversify by buying an unrelated firm. Furthermore, the downward trend in the CAAR could also reflect the anticipated and often overlooked problems in post-merger firms associated with the integration of two unrelated entities into an efficient whole.

As a comparison, the CAAR plot of the sample of acquiring firms in the related acquisitions is shown in Figure 2. The feature of the plot is that the CAAR for the acquiring firms fluctuates in a fairly narrow band throughout the period and there are no major increases or decreases in CAAR. Thus there is evidence that investors in acquiring firms that pursue related acquisitions anticipate this behaviour and expect the benefits almost a year before the actual merger.

There is some downward revision some $5-10$ weeks subsequent to the announcement. From weeks 10 to 20 there are significantly positive average abnormal returns, leading to a sharp rise in the CAAR plot. This is the period during which the target firm is delisted, and indicates that the delisting has some informational content. A year after the merger the net CAAR is $7 \%$, compared to the $-14 \%$ of the unrelated sample. According to Figures 1 and 2 it appears that the pursuance of a related acquisition policy increases value whilst an unrelated acquisition policy decreases value.

Many of the mergers in the related acquisitions sample resulted in a concentration effect in those particular

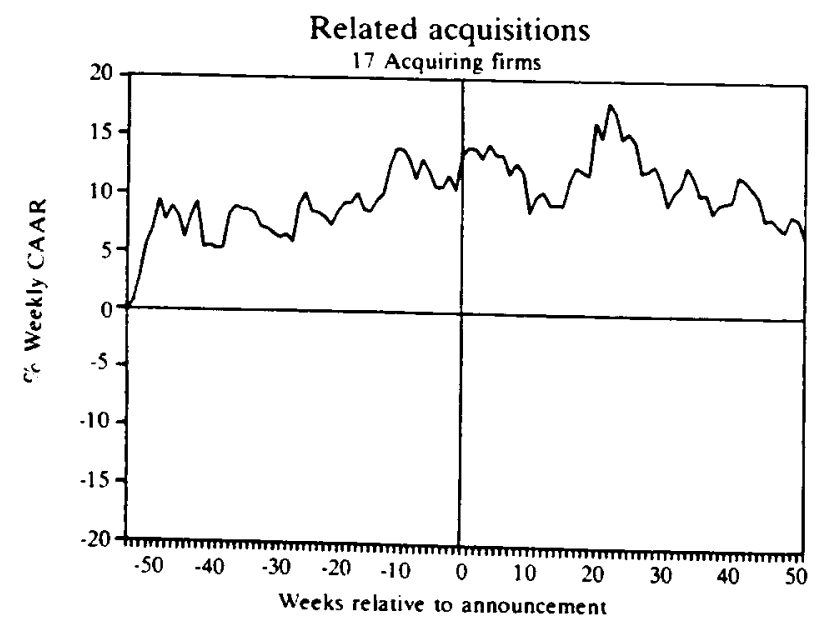

Figure 2 CAAR plot for acquiring firms in related mergers (sample 1.2)

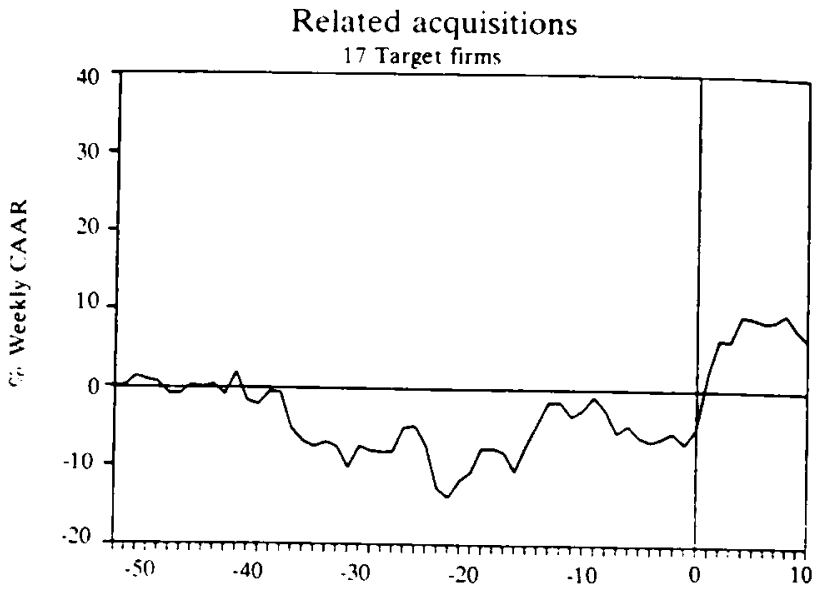

Figure 3 CAAR plot for target firms in related mergers (sample 1.2)

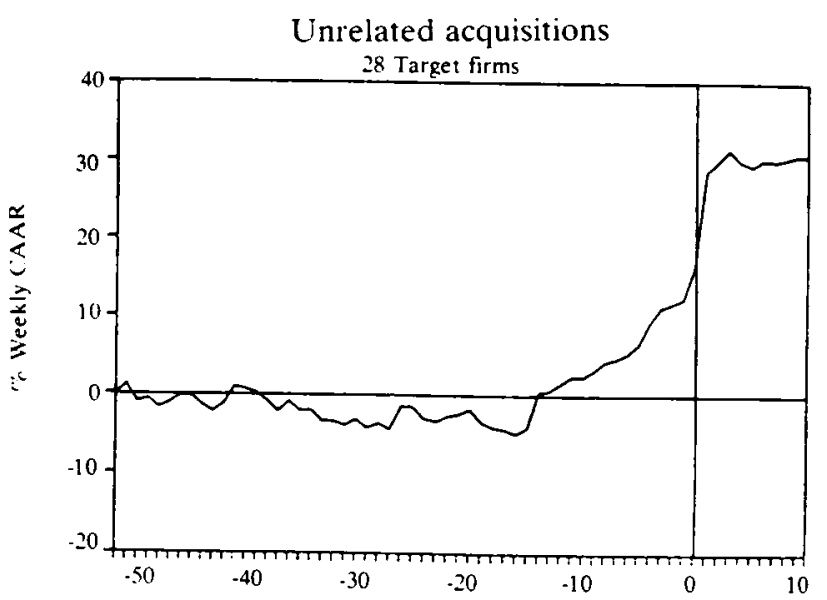

Figure 4 CAAR plot for target firms in unrelated mergers (sample 1.1)

industries, for example C.G. Smith Sugar and Illovo Sugar, Anglo American Properties and Sorec, Kohler and DRG(SA), Nampak and Premier Paper, amongst others. The positive CAAR's exhibited by the sample could be a reflection of the market's perception of the benefits accruing from market concentration and the characteristics of monopoly power associated with it.

Figures 3 and 4 show the CAAR plot for the samples of related and unrelated targets. Both samples exhibit a strong announcement effect although the CAAR after the announcement reaches $30 \%$ for unrelated acquisitions compared to only $10 \%$ for related acquisitions. Furthermore, in the case of the unrelated acquisitions the CAAR starts moving sharply upwards some 15 weeks before the announcement whilst most of the movement occurs from only one week before the announcement for the related acquisitions.

The CAAR for the target firm is a reflection of the market's perception of what premium the acquiring firm is willing to pay in order to complete the merger. Thus management of firms pursuing an unrelated acquisition strategy appear to be willing to pay more for the target than those following a related acquisition strategy. This is reflected in the CAAR performance of the acquiring 
firm subsequent to the announcement where CAAR's of acquiring firms involved in unrelated acquisitions drop away after the announcement (see Figure 1).

The CAAR plot for related acquisition target firms is negative over the 10 months prior to the merger and a positive CAAR does not develop until the announcement. This might indicate poor management in the target firms. The lower premium paid by the acquiring firms could be a result of poor management in the target firms or it could be a more accurate assessment of the value of the merger by the acquiring firm, compared to the valuation of target firms by the management of the acquiring firms in the unrelated merger sample.

For both related and unrelated mergers the gains to acquiring firms are minimal, indicating that investors perceive no economic gains to be had from the investment. Post announcement performance in fact shows that on average the net effect over the period considered is negative.

Prior control of the target firm by the acquiring firm

The CAAR plot for the sample of 18 acquiring firms which had effective control of the target at the time of the announcement is shown in Figure 5. The mean prior holding for this sample was $63,5 \%$.

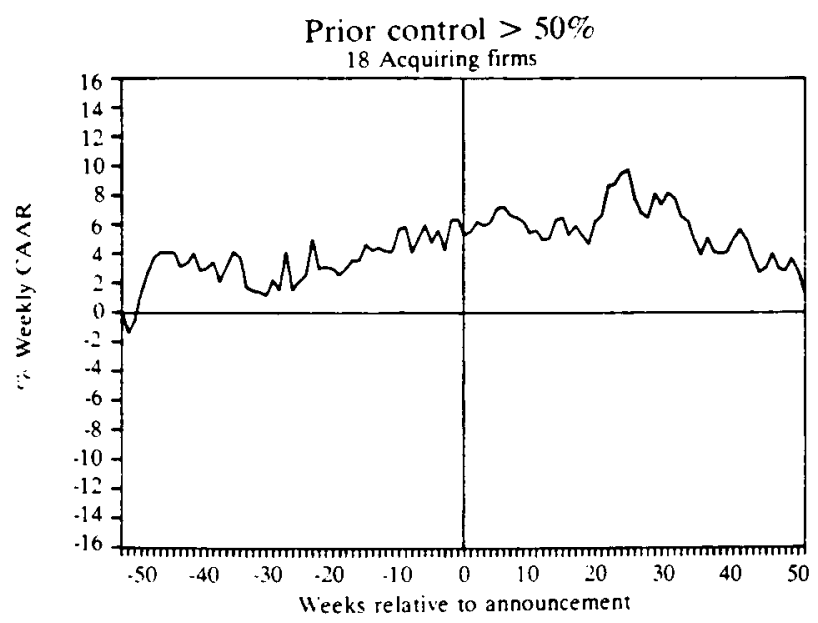

Figure 5 CAAR plot for acquiring firms with prior control $>50 \%$ (sample 2.1 )

The plot exhibits similar characteristics to the CAAR of the related acquisitions sample. However only three firms are common to both samples so the similarity in the two plots is not due to this effect. The overall CAAR fluctuates in a narrow band throughout the period with a net positive effect of $2 \%$ one year after the announcment. The fact that the acquiring firms are already deeply involved in the target firm would suggest that they know the business and perceive there to be benefits from the purchase of the minority interest. A plausible justification for the buy-out of the minority interest is an intention to re-organize the structure of the target firm within the acquiring firm, possibly signalling a change in direction for the group as a whole. This

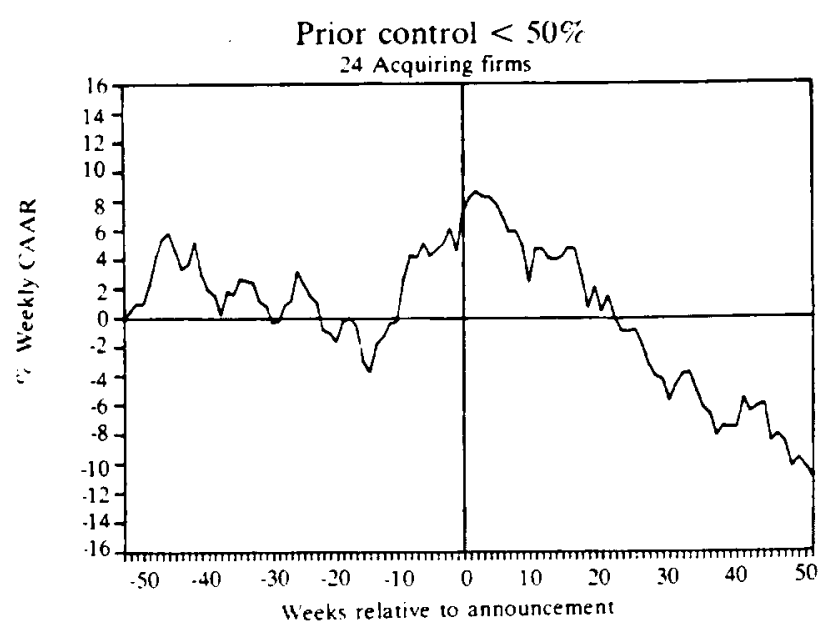

Figure 6 CAAR plot for acquiring firms with prior control $<50 \%$ (sample 2.2 )

might lead to improved profitability of the acquiring firm in the future as a result of this new strategic direction. However this profitability is not sustained and the CAAR plot exhibits a downward trend towards the end of the year after the merger announcement.

The CAAR plot for the acquiring firms that had less than $50 \%$ prior control at the time of the announcement is shown in Figure 6.

There is a strong upward effect some 15 weeks prior to the announcement reaching a peak of some $8,5 \%$ soon after the announcement, but all these gains are subsequently lost as investors revise their expectations when the true consequences of the merger become evident. In fact the CAAR of the acquiring firms was in a distinct downward trend before the upsurge and indications are that an acquisition strategy was being followed in order to boost sagging performance. However the benefits from merger do not appear to be achieved and there is a net reduction of shareholder wealth over the period studied.

The CAAR plot for the target firms in which prior control was more than $50 \%$ is shown in Figure 7 . The minority shareholders begin to anticipate the impending

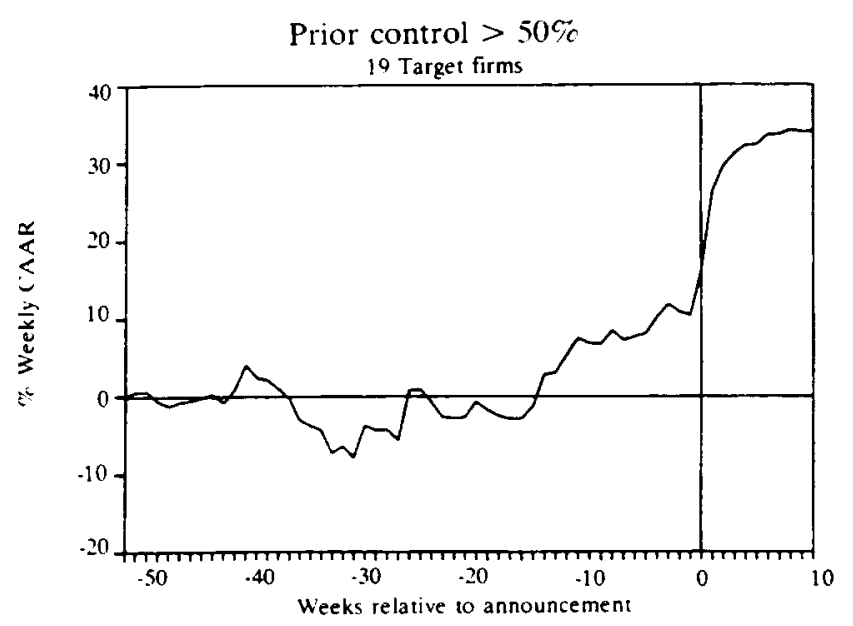

Figure 7 CAAR plot for target firms with prior control $>50 \%$ (sample 2.1) 
buyout some three to four months before the actual announcement. However the announcement still has strong informational content.

For the sample of target firms where prior control was less than $50 \%$, the announcement effect is very pronounced and positive returns are not experienced until the actual announcement week. Furthermore the target firms appear to have been performing poorly prior to the merger, a sensible reason for a takeover bid by the acquiring firm. This can clearly be seen in Figure 8.

It will be noted that the cumulated abnormal increase in return is $35 \%$ for the minority purchase as compared to $14 \%$ where control is less than $50 \%$.

The effect of relative size of the target firm to the acquiring firm

An acquisition was defined as 'large' if the ratio of the market capitalization of the target firm to that of the acquiring firm on the announcement date was greater than $25 \%$. The CAAR plots for acquiring firms involved in large and small acquisitions are found in Figures 9 and 10 respectively.

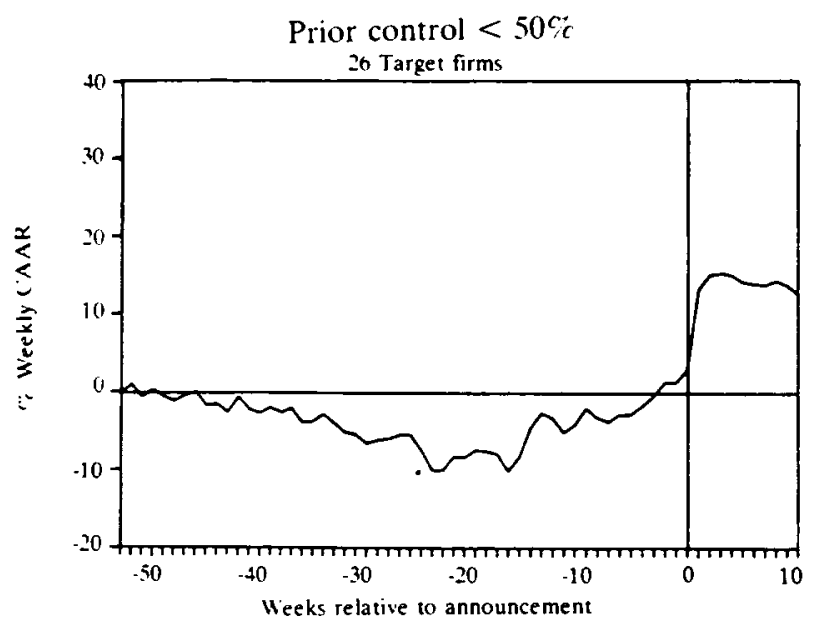

Figure 8 CAAR plot for target firms with prior control $<50 \%$ (sample 2.2)

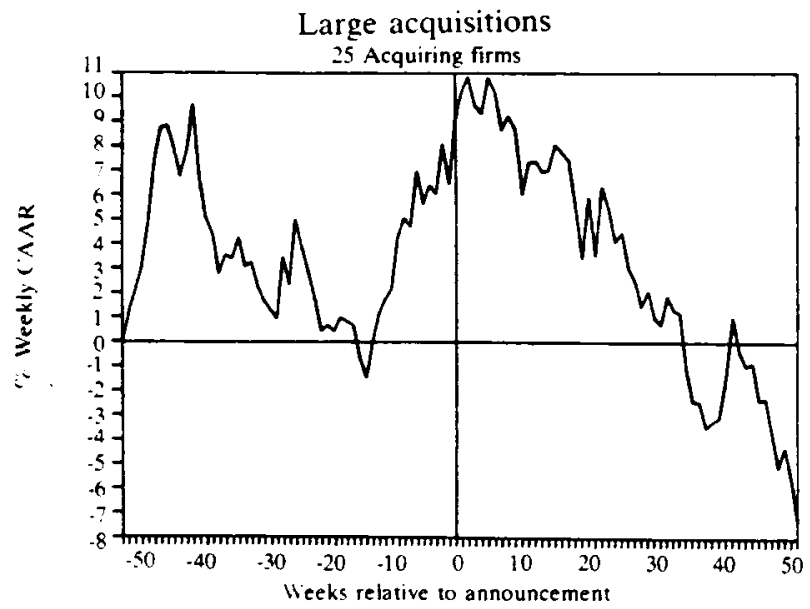

Figure 9 CAAR plot for acquiring firms in large mergers (sample 3.1)

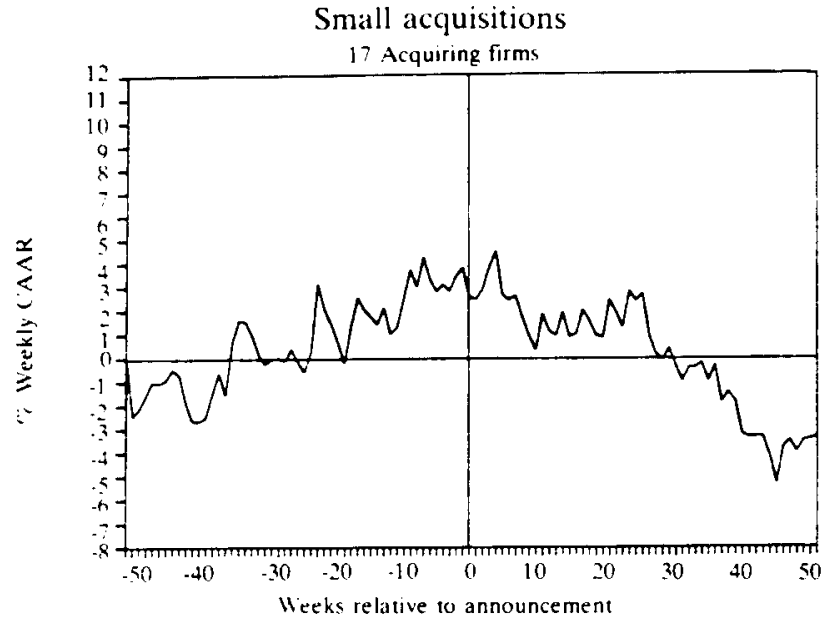

Figure 10 CAAR plot for acquiring firms in small mergers (sample 3.2)

Both plots show an upward trend starting some three months before the announcement, indicating that investors are anticipating potential merger benefits. The peak in each case is reached approximately three to four weeks after the announcement, at a level of nearly $11 \%$ for large acquisitions and $4 \%$ for small acquisitions. Thus the level of expected benefits is proportional to the stake involved. Indications of revised investor expectations about the benefits of the merger lead to a sharp downward trend in the CAAR from some four weeks after the announcement, with the net effect one year after the announcement being negative in both cases. Thus the size of the acquisition has no consistent effect on the wealth-creating possibilities by merger, i.e. small acquisitions are equally likely to be unsuccessful as large ones.

The CAAR plots for relatively small and large target firms are presented in Figures 11 and 12 respectively. Both plots exhibit a zero or negative CAAR before the announcement possibly indicating poor management in the target firms. The announcement effect is much more pronounced for large acquisitions than for small

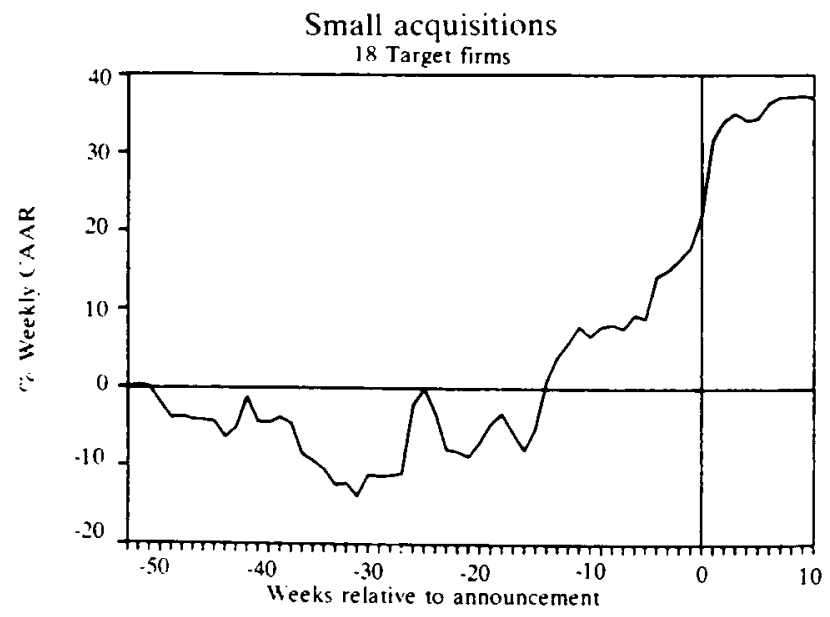

Figure 11 CAAR plot for target firms in small mergers (sample 3.2) 


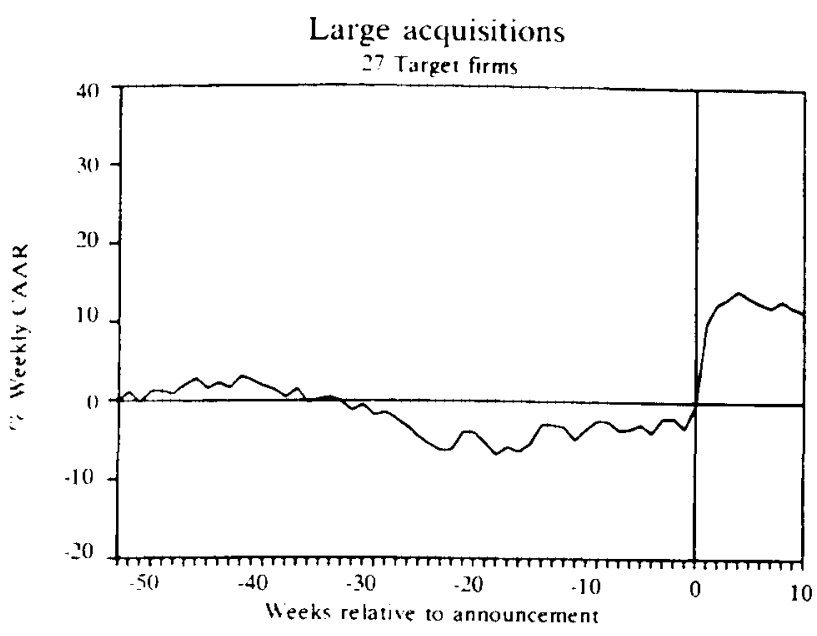

Figure 12 CAAR plot for target firms in large mergers (sample 3.1)

acquisitions where an upward trend begins some four months before the actual announcement. The magnitude of the announcement effect is however much larger in the case of small acquisitions where it rises to $38 \%$ soon after the announcement; in the case of large acquisitions it is only $13 \%$.

One justification for merger from the point of view of the target firm is a source of cheap capital from the acquiring firm. When the target is small relative to the acquiring firm this effect will be most marked (in percentage terms) and the CAAR plots for relatively small target firms exhibit this, rising significantly more just after the merger announcement than do the relatively large target firms.

\section{The role of the medium of exchange}

Those firms that used only cash or only shares as a medium of exchange for the financing of the merger were isolated. The CAAR plots for the acquiring firms involved in share exchange and cash exchange mergers are shown in Figures 13 and 14 respectively.

The sample of firms using only shares as a medium of

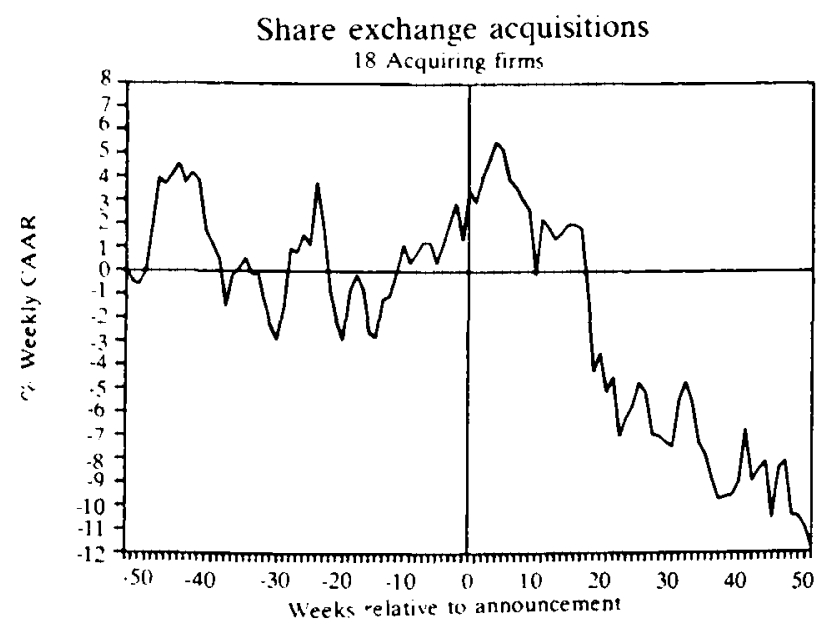

Figure 13 CAAR plot for acquiring firms in share exchange mergers (sample 4.1)

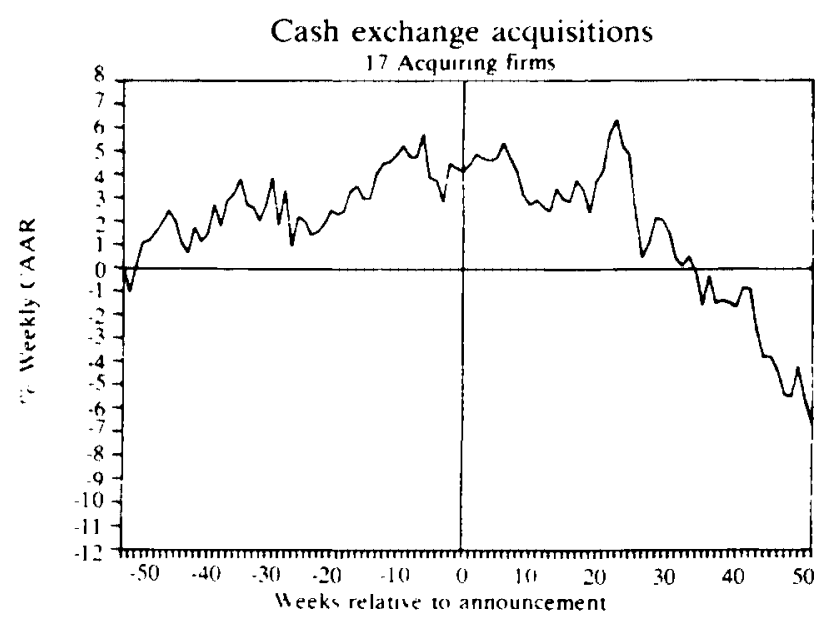

Figure 14 CAAR plot for acquiring firms in cash exchange mergers (sample 4.2)

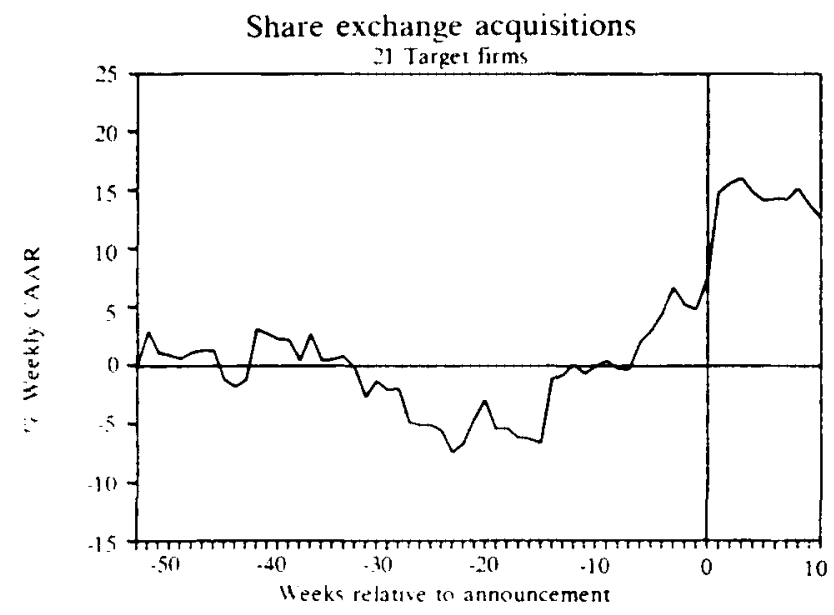

Figure 15 CAAR plot for target firms in share exchange mergers (sample 4.1)

exchange exhibits random behaviour up until the anticipation of benefits from the merger some three months before the announcement. The sample of cash exchange firms, however, exhibits gently increasing CAAR's in the year before the merger which fluctuate in a fairly narrow range. This could be due to the acquiring firm being successful and thus having excess sources of cash which it needs to invest. The positive CAAR's are either a reflection of the profitably performance of the acquiring firm or of the market's perceived benefits from acquisitions using the excess profits or cash. Whatever the reasons for the positive CAAR'S after the announcement, they are eroded rapidly and end up negative a year after the announcement. The decline is much quicker in the case of the share exchange sample. This could indicate worsened investor perception of the synergistic benefits possible from the merger, or the fact that the acquiring firm has given away equity and hence diluted shareholder's holdings.

The CAAR plots for the target firms in the samples of share exchange and cash exchange acquisitions are presented in Figures 15 and 16 respectively. 


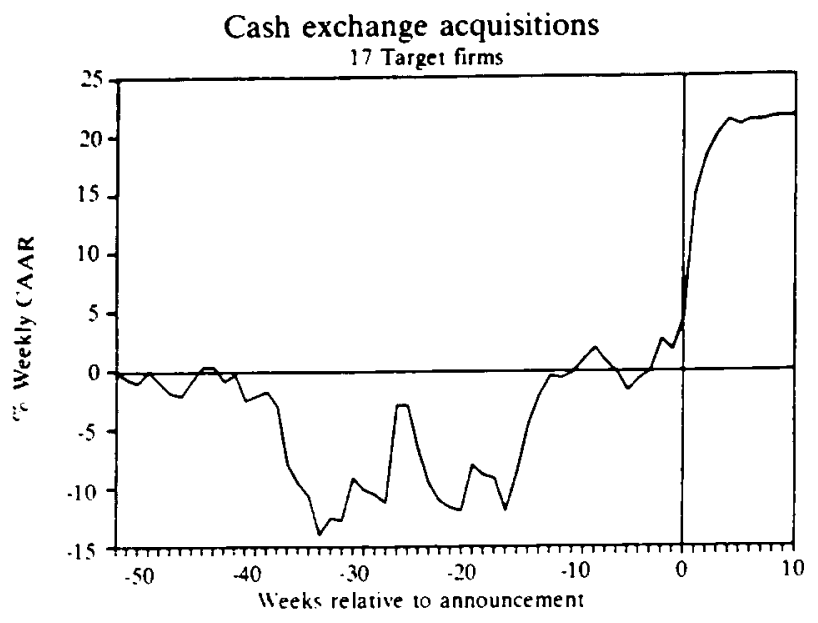

Figure 16 CAAR plot for target firms in cash exchange mergers (sample 4.2)

The overall characteristics of the two curves are similar for both samples and the CAAR plot for both samples exhibits a decline in the first half of the year prior to the merger announcement. The cumulated abnormal increase in returns after the announcement is $22 \%$ for cash exchange mergers and $16 \%$ for share exchange mergers. The shareholders from the target firm in the share exchange sample expect to benefit in the future from owning a small piece of a large and potentially profitable firm, and thus are prepared to accept a lower premium than they would if they were being paid in cash.

\section{Summary and Conclusions}

The following features emerge from the empirical results presented above: In the related mergers the acquiring firms on average do not lose value from merger while the targets show significant gains. In the case of unrelated mergers the acquirers lose, possibly due to the fact that they are unfamiliar with the business. In contrast, the target firms show massive gains. Similar results hold for the case where prior control is held by an acquiring firm, i.e. acquirers do not lose by merger if they held prior control, but their value is reduced if they did not have prior control. This may be due to the fact that acquirers who do hold prior control are involved in the target firm and hence are familiar with the business.

When relative size is considered it was observed that acquirers on average lost value by merger regardless of whether the target was small or large. However the target firms gained in both instances. An identical result held when the medium of exchange was the variable under consideration - acquiring firms decreased in value and targets gained.

A point that arises from this study is that the acquiring firms involved in merger activity do not tend to benefit in the short term from the merger while the target firms do experience abnormal positive returns around the announcement date. Although the characteristics employed to partition the sample are by no means exhaustive it has been shown that the general empirical results as shown by Affleck-Graves, Flach \& Jacobson (1987) hold irrespective of the variable considered to partition the sample.

\section{Acknowledgement}

Financial assistance rendered by the Human Sciences Research Council towards the costs of this research is hereby acknowledged. Opinions expressed or conclusions arrived at are those of the authors and not necessarily those of the HSRC.

\section{Notes}

1. It may be noted that in the above partitioning of the samples of 45 mergers the sum of the mergers in any two converse sub-samples is less than 45 . This arises because in several instances an acquiring firm merged with two or more targets on the same day. In this set of circumstances the characteristics of the acquiring firm were only analysed once so as to only contribute once to the overall results.

2. This form of the market-industry model may appear somewhat different to that used by Affleck-Graves, Flach \& Jacobson (1986) who define the expectations form of the model as

$$
E\left(R_{i t}\right)=\beta_{0}+\beta_{1} R_{m t}+\beta_{2}\left(S_{i t}-E\left(S_{i t}\right)\right)
$$

But this is simply

$$
\begin{aligned}
E\left(R_{i t}\right) & =\beta_{0}+\beta_{1} R_{m t}+\beta_{2} S_{i t}-\beta_{2} E\left(S_{i t}\right) \\
& =\beta_{0}+\beta_{1} R_{m t}+\beta_{2} S_{i t}-\beta_{2}\left(c+d R_{m t}\right)
\end{aligned}
$$

where $c$ and $d$ are constants, since the assumption is that the expected value of the sector is linearly related to the market. So

$$
\begin{aligned}
E\left(R_{i t}\right) & =\beta_{0}+\beta_{1} R_{m t}+\beta_{2} S_{i t}-c \beta_{2}-d \beta_{2} R_{m t} \\
& =\left(\beta_{0}-c \beta_{2}\right)+\left(\beta_{1}-d \beta_{2}\right) R_{m t}+\beta_{2} S_{i t} \\
& =\beta_{0}{ }^{\prime}+\beta_{1} R_{m t}+\beta_{2} S_{i t}
\end{aligned}
$$

which is the expectations form of equation (1).

\section{References}

Affleck-Graves, J.F., Flach, T.P. \& Jacobson, A.S. 1987. The Effect of Merger Announcements on the Share Prices of the Acquired and Acquiring Companies. S. Afr. J. Bus. Mgmt. In press.

Brealey, R. \& Myers, S. 1981. Principles of Corporate Finance. McGraw-Hill, Tokyo.

Brews, P. 1987. Corporate growth through Mergers and Acquisitions: Viable Strategy or Road to Ruin? S. Afr. J. Bus. Mgmt. vol. 18, 10-20.

Dodd, P. 1980. Merger Proposals, Management Discretion and Stockholder Wealth. J. Finan. Econ. vol. 8, 105-138

Fama, E.F., Fisher, L., Jensen, M. \& Roll, R. 1969. The Adjustment of Stock Prices to New Information. Intern. Econ. Rev., February 1969, 1-21.

Halpern, P.J. 1973. Empirical Estimates of the Amount and Distribution of Gains to Companies in Mergers. J. Bus., October 1973, 554-575. 
Jensen, M.C. \& Ruback, R.S. 1983. The Market for Corporate Control. J. Finan. Econ. vol. 11, 5-50.

Kitching. J. 1967. Why do Mergers Miscarry? Harv. Bus. Rev. vol. $45,84-101$.

Langeticg. T. 1978. An Application of a Three Factor Performance Index to Measure Stockholder Gains from Merger. J. Finan. Econ. vol. 6, 365-384.

Mandelker, G. 1974. Risk and Return: The Case of Merging Firms. J. Fin. vol. 1, 303-335.
Peters, T.J. \& Waterman, R.H. 1982. In Search of Excellence. Harper and Row, New York

Rowlinson, C.E. 1984. The Change in the Performance of a Small Business Acquired by a Large Corporation. Unpublished Research Thesis, University of the Witwatersrand, Johannesburg.

Shad, S.R. 1969. The Financial Realities of Mergers. Harv. Bus. Rev. vol. 47, 133-146.

\begin{tabular}{|c|c|c|c|c|c|c|c|c|c|c|c|}
\hline No & Acquiring firm & Target firm & 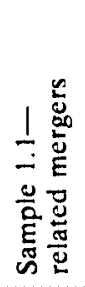 & 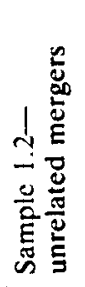 & 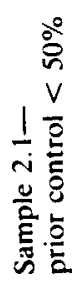 & 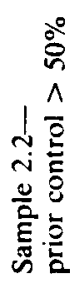 & 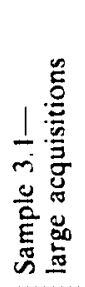 & 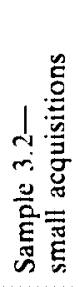 & 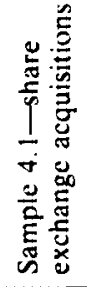 & 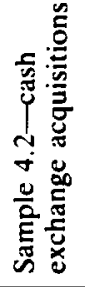 & $\begin{array}{c}\text { Announcement } \\
\text { date }\end{array}$ \\
\hline 1 & Anglo American Corp. & Rand Selections & & $\mathbf{x}$ & $\mathbf{x}$ & & $\mathrm{x}$ & & $\mathbf{x}$ & & $19 / 01 / 77$ \\
\hline 2 & Anglo American Ind. Corp. & Bruynzeel Plywood & & $\mathbf{x}$ & & $\mathbf{x}$ & & $\mathbf{x}$ & $\mathbf{x}$ & & $18 / 08 / 76$ \\
\hline 3 & Anglo American Propertics & Sorec & $\mathbf{x}$ & & $x$ & & $\mathrm{x}$ & & $x$ & & $26 / 11 / 80$ \\
\hline 4 & Barlow Rand & CJ Fuchs & & $\mathbf{x}$ & $x$ & & & $\mathbf{x}$ & & & $08 / 06 / 77$ \\
\hline 5 & Bluc Circle & Hubert Davies & & $x$ & & $\mathbf{x}$ & $\mathbf{x}$ & & & $\mathbf{x}$ & $23 / 03 / 77$ \\
\hline 6 & CG Smith Sugar & Illovo Sugar & $\mathbf{x}$ & & $\mathbf{x}$ & & & $x$ & & & $09 / 09 / 77$ \\
\hline 7 & Amalgamated Retail & ABC Shoe Company & $\mathbf{x}$ & & $\mathbf{x}$ & & & $\mathbf{x}$ & & $\mathbf{x}$ & $20 / 10 / 83$ \\
\hline 8 & Anglo Alpha Cement & Hippo Holdings & & $x$ & & & $x$ & & & $\mathbf{x}$ & $16 / 03 / 77$ \\
\hline 9 & Dorman Long & Bus Industries SA & $\mathbf{x}$ & & & $\mathbf{x}$ & & $\mathbf{x}$ & & $\mathbf{x}$ & $19 / 10 / 78$ \\
\hline 10 & Federale Volksbeleggings & SA Druggists & & $\mathrm{x}$ & & $\mathrm{x}$ & $\mathbf{x}$ & & & & $09 / 08 / 83$ \\
\hline 11 & General Mining & Union Corporation & & $\mathbf{x}$ & & $\mathbf{x}$ & $\mathbf{x}$ & & $\mathbf{x}$ & & $19 / 12 / 79$ \\
\hline 12 & General Mining & Xactics & & $\mathrm{x}$ & & $\mathbf{x}$ & & $x$ & & $\mathbf{x}$ & $14 / 07 / 83$ \\
\hline 13 & Hunt Leuchars and Hepburn & WF Johnstone & & $\mathrm{x}$ & $\mathbf{x}$ & & $\mathbf{x}$ & & & & $10 / 12 / 81$ \\
\hline 14 & Johannesburg Cons. Inv. & Tavistock Collieries & & $\mathbf{x}$ & & $\mathbf{x}$ & $\mathrm{x}$ & & & $\mathrm{x}$ & $24 / 03 / 81$ \\
\hline 15 & Johannesburg Cons. Invest & Steelbright & & $\mathbf{x}$ & & $\mathrm{x}$ & & $\mathbf{x}$ & & $\mathbf{x}$ & $14 / 12 / 78$ \\
\hline 16 & Kohler & DRG(SA) & $\mathbf{x}$ & & $\mathbf{x}$ & & & $\mathbf{x}$ & & $\mathrm{x}$ & $03 / 02 / 83$ \\
\hline 17 & Metal Box & Metal Rolling \& Tube Hold & $\mathbf{x}$ & & & $x$ & & $\mathbf{x}$ & & $\mathbf{x}$ & $29 / 08 / 77$ \\
\hline 18 & Nampak & Premier Paper & $\mathbf{x}$ & & & $x$ & & $\mathbf{x}$ & & $\mathbf{x}$ & $20 / 04 / 83$ \\
\hline 19 & Power Technologies & Scottish Cables & $\mathbf{x}$ & & $\mathbf{x}$ & & $\mathbf{x}$ & & $\mathbf{x}$ & & $22 / 03 / 85$ \\
\hline 20 & Rembrandt Group & Oude Meester & & $\mathbf{x}$ & & $x$ & & $x$ & & $\mathbf{x}$ & $11 / 08 / 78$ \\
\hline 21 & Sage Holdings & Schachat Holdings & & $\mathbf{x}$ & & $\mathbf{x}$ & $\mathbf{x}$ & & & $\mathbf{x}$ & $30 / 11 / 78$ \\
\hline 22 & Sam Steel & Steel and Barnet & $\mathbf{x}$ & & & $\mathbf{x}$ & $x$ & & & & $31 / 07 / 78$ \\
\hline 23 & Union Platinum & Potgietersrus Platinum & & $\mathbf{x}$ & $\mathbf{x}$ & & $x$ & & $\mathbf{x}$ & & $17 / 05 / 76$ \\
\hline 24 & Union Platinum & Waterval Platinum & & $\mathbf{x}$ & $\mathbf{x}$ & & $\mathbf{x}$ & & $\mathbf{x}$ & & $17 / 05 / 76$ \\
\hline 25 & Seardel & Dubin Investments & $\mathbf{x}$ & & $\mathbf{x}$ & & $x$ & & & $\mathbf{x}$ & $06 / 03 / 81$ \\
\hline 26 & Sentrachem & Federale Kunsmis & $\mathbf{x}$ & & $\mathrm{x}$ & & $x$ & & $x$ & & $29 / 11 / 79$ \\
\hline 27 & UDC Holdings & Ryan Nigel Holdings & & $\mathrm{x}$ & & $\mathrm{x}$ & $x$ & & & $\mathrm{x}$ & $04 / 04 / 77$ \\
\hline 28 & Metkor Investments & Fowler Holdings & & $x$ & & $\mathbf{x}$ & & $\mathrm{x}$ & $\mathbf{x}$ & & $05 / 04 / 78$ \\
\hline 29 & Tongaat-Hulett & Tongaat Corogroup & & $\mathbf{x}$ & & $\mathbf{x}$ & $x$ & & & $\mathbf{x}$ & $02 / 09 / 83$ \\
\hline 30 & Trans Natal Coal & Alfred Mcalpine & $\mathbf{x}$ & & $\mathbf{x}$ & & & $\mathbf{x}$ & $\mathbf{x}$ & & $30 / 08 / 85$ \\
\hline 31 & Union Corporation & Geduld Investments & & $x$ & $\mathbf{x}$ & & & $\mathbf{x}$ & $\mathrm{x}$ & & $26 / 07 / 76$ \\
\hline 32 & Volkskas Group & Bank OFS & $\mathbf{x}$ & & $\mathbf{x}$ & & & $\mathbf{x}$ & $\mathbf{x}$ & & $25 / 09 / 81$ \\
\hline 33 & W \& A Investments & Burlington Hosiery & $\mathbf{x}$ & & $\mathbf{x}$ & & $x$ & & & $x$ & $11 / 05 / 77$ \\
\hline 34 & Welkom GM Co Ltd & Free State Saaiplaas & $\mathbf{x}$ & & $\mathbf{x}$ & & $\mathbf{x}$ & & $\mathbf{x}$ & & $18 / 12 / 80$ \\
\hline 35 & Woolworths & Truworths & $\mathbf{x}$ & & $\mathbf{x}$ & & $\mathbf{x}$ & & & & $16 / 03 / 81$ \\
\hline 36 & Kirsh Trading & Metcash & & $\mathrm{x}$ & $\mathbf{x}$ & & $x$ & & $\mathbf{x}$ & & $05 / 10 / 83$ \\
\hline 37 & Kirsh Trading & Russel Holdings & & $\mathbf{x}$ & $\mathbf{x}$ & & $\mathbf{x}$ & & $\mathbf{x}$ & & $05 / 10 / 83$ \\
\hline 38 & Metcor Investments & Wispeco & & $\mathrm{x}$ & & $\mathrm{x}$ & $\mathrm{x}$ & & $\mathbf{x}$ & & $27 / 11 / 79$ \\
\hline 39 & Metkor Investments & Hart Ltd & & $\mathbf{x}$ & $\mathbf{x}$ & & & $x$ & $\mathbf{x}$ & & $27 / 11 / 79$ \\
\hline
\end{tabular}




\section{Appendix A Continued}

\begin{tabular}{|c|c|c|c|c|c|c|c|c|c|c|}
\hline No & Acquiring firm & Target firm & 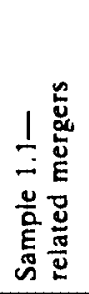 & 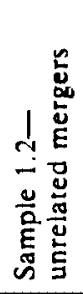 & 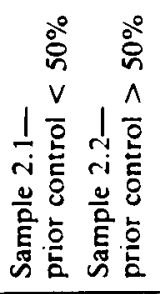 & 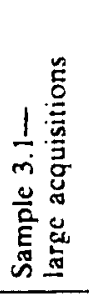 & 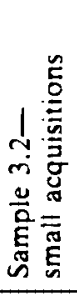 & 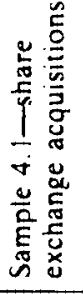 & 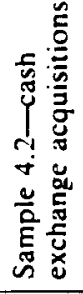 & $\begin{array}{c}\text { Announcement } \\
\text { date }\end{array}$ \\
\hline 40 & UC Investments Ltd & Sentrust & & $\mathbf{x}$ & $x$ & $x$ & & $\mathrm{x}$ & & $15 / 07 / 83$ \\
\hline 41 & Standard Bank Inv. Co. & Hesperus Holdings & & $\mathbf{x}$ & $x$ & & $\mathrm{x}$ & & $x$ & $29 / 10 / 85$ \\
\hline 42 & Lucem Holdings & Brick \& Clay Holdings & & $\mathbf{x}$ & $\mathbf{x}$ & $\mathbf{x}$ & & & & $22 / 02 / 80$ \\
\hline 43 & Huletts & Tongaat & & $x$ & $\mathbf{x}$ & $\mathrm{x}$ & & $\mathbf{x}$ & & $27 / 01 / 82$ \\
\hline 44 & East Driefontein & West Driefontein & $x$ & & $\mathbf{x}$ & $\mathbf{x}$ & & $\mathbf{x}$ & & $22 / 04 / 81$ \\
\hline 45 & CNA Investments & Gallo Africa & & $\mathrm{x}$ & $\mathbf{x}$ & $\mathrm{x}$ & & $\mathrm{x}$ & & $31 / 03 / 83$ \\
\hline
\end{tabular}

